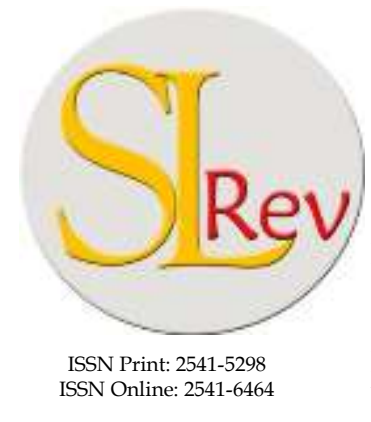

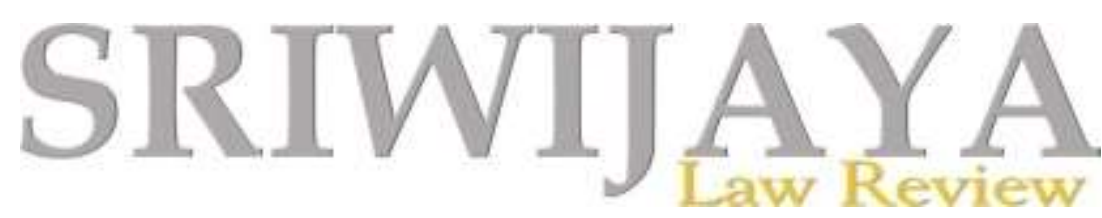

Editorial Office: Faculty of Law, Sriwijaya University, Jalan Srijaya Negara, Palembang, South Sumatra 30139, Indonesia. Phone: +62711-580063Fax: +62711-581179

E-mail: sriwijayalawreview@unsri.ac.id| sriwijayalawreview@gmail.com Website: http://journal.fh.unsri.ac.id/index.php/sriwijayalawreview

\title{
Regulatory Issues on Raising Capital through Debentures by Public Companies in the United Kingdom
}

\author{
Mohammad Belayet Hossain*
}

\begin{abstract}
Nowadays, it is common for the loans to be aggregated as a lump sum, which is then advanced to the company by the trustees. In this situation, the lenders subscribe for debenture stock, sometimes called loan stock, out of the fund. As with shares, such stock forms part of the company's securities, which can be traded in the Stock Exchange. The lenders might require security for their loans. In this situation, a company will charge its property to secure the loan. In light of the Companies Act 2006 of the United Kingdom, this paper will analyze the various mechanisms whereby public companies raise money through debentures and the regulatory consequences of doing so. The companies legislation requires certain particulars of the charge to be registered. Therefore, this paper aims to reflect on: (a) how public companies borrow its capital through debentures or debenture stock; (b) what types of charge the public companies could issue to lenders as security; (c) how to differentiate between fixed and floating charges. This paper will also examine the question of priority among competing creditors and inconsistent decisions of the court regarding fixed and floating charges. The objectives of this paper are to: describe the meaning of 'debenture', discuss the dispute relating granting a fixed charge over book debts, sketch the priority of charges and the statutory listing system, describe the meaning of book debts, explain the character of and the differences between floating and fixed charges. This paper will provide recommendations that could be taken into consideration for future amendments of the Companies Act 2006.
\end{abstract}

Keywords: Debentures; Public Company; Raising Capital; Regulatory Issues; The United Kingdom.

\section{ARTICLE HISTORY:}

\section{DOI: 10.28946/sIrev.Vol3.Iss2.252.pp111-123}

Received: Feb 14, 2019;

Reviewed: Jul 7, 2019;

Accepted: Jul 27, 2019;

Published: Jul 31, 2019.

* Faculty of Law, Chittagong Independent University Bangladesh. Email: galib@ciu.edu.bd

\section{INTRODUCTION}

In addition to raising money by issuing shares, companies may also raise capital by borrowing. The capacity to borrow money may be subject to restrictions in the company's constitution, i.e., its memorandum or articles of association. The majority of private companies have $£ 100.00$ or less issued share capital and they heavily relied on the commercial banks for loans to finance their trade activities. In such a case, banks do not take risks; they will require security for their loans. ${ }^{1}$

A company that wishes to raise a large loan may also go into the investment market to attract sums from many investors at the

1 Lorraine Talbot, 2015. Critical Company Law. Routledge, p55. 
same time and on the same terms. The procedure is similar to making a share offering, although such lenders do not become members of the company (with rights in the company). Instead, they have its creditors (with rights against the company). In practice, the rights of such lenders are written under a trust deed, and trustees represent the interests of the investors. This practice has an administrative advantage for the company only dealing with the trustees rather than with individual lender; the trustees deal with the lenders. The trust deed will set out the procedure for creditors' meetings and voting.

\section{ANALYSIS AND DISCUSSION \\ Debentures}

In simple terms, a debenture is only a certificate, which proves the debts of the company. ${ }^{2}$ In Levy v Abercorris Slate and Slab Co., Chitty J. defines debentures as "A document, which either creates a debt or acknowledges it, and any document, which fulfills either of these conditions."

In Knightsbridge Estates Trust Ltd v Byrne, Mr. Byrne's insurance company granted a loan to Knightsbridge Estates and as per contract, the loan should be returned within forty years but if the principal amount of loan is returned before that period, then the total amount of interest would be lessened. Knightsbridge Estates wanted to repay the actual loan of $£ 310,000.00$ and argued that the lengthy refund plan was an obstruction on the equity of redemption. In contrast, Byrne argued that as per section 74 of the CA $1929^{3}$, the

\footnotetext{
2 Levy v Abercorris Slate and Slab Co (1887) $36 \mathrm{Ch}$ D 215; see also Knightsbridge Estates Trust v Byrne [1940] AC 613.

3 Now section 739, Companies Act 2006.
}

contract was not under the rule of equity on clogs of redemption. Lord Greene MR in the Court of Appeal held that the loan amount should be considered as a debenture, which was upheld by the House of Lords. Viscount Maugham stated:

"My Lords, loans made to limited companies on the security of their assets are in general very different from loans made to individuals. Companies may be wound up, in which event their debts have, if possible, to be paid, but they do not die. To the knowledge of both the company and the lender, the loan is intended in most cases to be of the nature of a permanent investment. The former can only in the rarest of circumstances be at the mercy of the latter. There is no likelihood of oppression being exerted against the company. Considerations such as these make it manifest that clauses in debentures issued by companies making them irredeemable or redeemable only after long periods or on contingencies ought to be given validity. It may be conceded that the ground for excluding the rule in equity is stronger in the case of a series of debentures issued in one of the usual forms than in the case of mortgages of land to an individual, but some of the reasons still remain. It is difficult to see any real unfairness in a normal commercial agreement between a company and (for example) an insurance society for a loan to the former on the security of its real estate for a very prolonged term of years. Both parties may be equally desirous that the mortgage may have the quality of permanence. There is a great deal to be said in such a case for freedom of contract."

There are two additional categories of debenture: a) Private Debenture: it is a kind of instrument, which acknowledges that debt is entered privately when a lender gives a loan to the company. b) Public Debenture: it offers debt to the public at large, which could be bought and sold by the public, similar to shares. When the debenture matures, the companies are liable to pay the debenture owner with interest.

However, s.738 of the CA 2006 provides the definition of debenture, which seems incomplete: 
“'Debenture' includes debenture stock, bonds and any other securities of a company, whether constituting a charge on the assets of the company or not."

Therefore, the above definition covers the mortgage of freehold estate as a security and a charge on its property. When a company borrows money from so many diverse lenders on similar conditions, then these lenders form a 'class' and it is called debenture stock. The rights of the lenders are written in a trust deed and frequently, the banks acting as a trustee represents the interests of the lenders. The trust deed usually covers the following condition: a) the requirement to give the primary amount with interest; b) any kind of security given for the mortgage; c) the measures that would initiate the enforceability of security.

\section{Company Charges}

Creditors will habitually demand security from a borrower before lending capital because if the company fails to repay the creditors, they can inflict the security interest. The chargee might then sell the property in the event of default. The creditors require security because they want to make sure their priority over other general creditors in case of winding-up of the company. Legal charges cannot be created over personality that is, property other than legal interests in land - so equitable charges give companies greater flexibility in creating a security interest over a wider range of assets.

Granting security by a company creates a burden on the asset and the title to the secured property is not transferred to the creditor, however, through the court order, the creditor enjoys a right to make the security available. ${ }^{4}$ The company most commonly provides fixed and floating charges as security interests. In the National Provincial Bank case, Fylde Bacon Curing Co. had two creditors who were clashing to seize the company's asset. On $16^{\text {th }}$ July 1921 , the National Provincial Bank entered into a contract, which stated that "its lease 'demised' for 996 years over 'plant used in or about the premises' in return for a loan". An unsecured creditor named $\mathrm{Mr}$ Charnley argued that the word 'demise' should have things concerning land and did not include several company vans but the bank, in contrast, argued that the vans charge was first and registered under s. 93 of the CA $1908 .^{5}$

Bankes LJ and Scrutton LJ gave the first two judgments in the Court of Appeal and held that the essence of the instrument was that a charge was created and the bank registered it appropriately. Atkin LJ said that a charge depends on the intention of the parties and also stated that:

"The first question that arises is whether or not this document does create a mortgage or charge, and to determine that it is necessary to form an idea of what is meant by a "charge". It is not necessary to give a formal definition of a charge, but I think there can be no doubt that wherein a transaction for value both parties evince an intention that property, existing or future, shall be made available as security for the payment of a debt, and that the creditor shall have a present right to have it made available, there is a charge, even though the present legal right which is contemplated can only be enforced at some future date, and though the creditor gets no legal right of property, either absolute or special, or any legal right to posses-

\footnotetext{
$4 \quad$ National Provincial Bank v Charnley [1924] 1 KB 431.

5 Now s. 860 of the Companies Act 2006. See also Ferran, E. 2014. Company Law and Corporate Finance. Oxford: Oxford University Press, p134.
} 
sion, but only gets a right to have the security made available by order of the Court. If those conditions exist, I think there is a charge. If, on the other hand, the parties do not intend that there should be a present right to have the security made available, but only that there should be a right in the future by agreement, such as a license, to seize the goods, there will be no charge."

\section{Fixed and Floating Charges \\ Fixed charges}

When any company grants a fixed charge over a certain asset to a creditor (for example, storehouse), automatically, the creditor's (chargee) right is attached to the asset like mortgage and in such a case; the company's (chargor's) authority is limited to deal with the property. As a result, the company must acquire the chargee's permission before deal with the charges property. Lord Millett stated in Agnew $v$ Commissioner of Inland Revenue ${ }^{6}$ that:

"A fixed charge gives the holder of the charge an immediate proprietary interest in the assets subject to the charge which binds all those into whose hands the assets may come with notice of the charge."

In Agnew $v$ Commissioner of Inland Revenue (more commonly referred to as $R e$ Brumark Investments Ltd), Brumark Investments Ltd had taken a loan from its bank, Westpac and gave security over the debts. The conditions were that its security would be a fixed charge but considered as a floating charge when it collects the profits. Therefore, the Brumark was collecting the debts freely and used the profits for its own business. When the Burmark went into receivership, the receivers started to collect

[2001] 2 AC 710. See further Aiyar, Shekhar, Charles W. Calomiris, John Hooley, Yevgeniya Korniyenko, and Tomasz Wieladek, 2014, "The international transmission of bank capital requirements: Evidence from the UK," Journal of Financial Economics 113 (3). pp368-382. the due debts. Fisher $\mathrm{J}$ referred to the agreement between the parties and held that outstanding debts, which were collected by the receiver, would be considered as a fixed charge. However, this decision was overturned by the New Zealand Court of Appeal, which held that it was a floating charge not a fixed charge because the fact that Brumark was allowed to collect its debts for its account removed it from bank's security. The Privy Council suggested, "it was indeed a floating charge. It said the court's task is not to ask whether the parties intended to create a fixed or floating charge but to ask what rights the parties intended to create, and then decide as a matter of law whether it is fixed or floating". 7

Moreover, Professor Goode ${ }^{8}$ has stated that a charge or security interest shall be a right in rem, which is formed by a grant or declaration of trust. If the charge is fixed, then it will imply that the debtor has limited authority over the property or property in question.

\section{Floating Charges}

Due to the acquisition or disposal, a floating charge usually fluctuates partly or fully over the chargor's property. In doing so, a floating charge is recognized as one of equity's most luminous creations. ${ }^{9}$ In re Panama, New Zealand, and Australian Royal Mail $\mathrm{Co}^{10}$ was an English case where a floating charge was at first recognized. After that, floating charges popularity

7 See also Re New Bullas Trading Ltd [1994] 1 BCLC 485; Siebe Gorman \& Co Ltd v Barclays Bank Ltd [1979] 2 Lloyd's Rep 142; In re Keenan Bros Ltd [1986] BCLC 242.

8 Sir Royston Miles "Roy" Goode CBE QC FBA is an academic commercial lawyer in the United Kingdom

9 Roy Goode, Company Charges: Spectrum and Beyond, Oxford University Press, 2006.

10 [1870] 5 Ch App 318. 
increased and extended swiftly, but until Lord Walker described it as "The floating charge had become a cuckoo in the nest of corporate insolvency." 11

However, arguments against the outcome of floating charges increased, until Lord Macnaghten ultimately proclaimed in Salomon v A Salomon \& Co Ltd: ${ }^{12}$

"For such a catastrophe as has occurred in this case some would blame the law that allows the creation of a floating charge. But a floating charge is too convenient a form of security to be lightly abolished. I have long thought, and I believe some of your Lordships also think, that the ordinary trade creditors of a trading company ought to have a preferential claim on the assets in liquidation in respect of debts incurred within a certain limited time before the winding-up. But that is not the law at present. Everybody knows that when there are a winding-up debenture-holders generally step in and sweep off everything, and a great scandal it is."

Commercial assets, such as plants, stock in trade, book debts (receivables) could be considered for a floating charge. An individual is not allowed to endowment floating charges due to the legal condition that the property charged must be particularly described in the instrument. ${ }^{13}$ The difference between a floating charge with fixed charge is - the company is not required to acquire the chargee's permission prior to deal with the property during the usual course of business. However, in case of any default on repayment, winding-up of the company or any other crystallizing incident, a floating charge will convert into a fixed charge over the property in question. ${ }^{14}$

11 Re Spectrum Plus Ltd [2005] UKHL 41.

12 [1986] UKHL 1, [1897] AC 22.

13 See the Bills of Sales Act 1878.

14 Adrian J Walters, 2015. "Statutory Erosion of Secured Creditors' Rights: Some Insights From the United Kingdom." U. Ill. L. Rev. 543.

\section{Determining Whether A Charge Is Float- ing or Fixed}

The position of chargees against the general body of creditors raises concern when any company goes into liquidation, then it becomes very important to distinguish between a floating and fixed charge. ${ }^{15}$ Romer LJ in Re Yorkshire Woolcombers Association, ${ }^{16}$ listed the following distinctive characteristics of a floating charge:

"it is a charge on a class of assets of a company present and future; that class is one which, in the ordinary course of the business of the company, would be changing from time to time; and you find that by the charge it is contemplated that, until some future step is taken by or on behalf of those interested in the charge, the company may carry on its business in an ordinary way as far as concerns the particular class [charged]."17

Moreover, Lord Phillips MR in National Westminster Bank plc v Spectrum Plus Ltd, ${ }^{18}$ stated:

"Initially it was not difficult to distinguish between a fixed and a floating charge. A fixed charge arose where the chargor agreed that he would no longer have the right of free disposal of the assets charged, but that they should stand as security for the discharge of obligations owed to the chargee. A floating charge was normally granted by a company, which wished to be free to acquire and dispose of assets in the normal course of its business, but to make its assets available as security to the chargee in priority to other creditors should it cease to trade. The hallmark of the floating charge was the agreement that the chargor should be free to dispose of his assets in the normal course of a business unless and until the chargee intervened. Up to that moment, the charge 'floated."
15 Mariana Zhuravel, 2015. "Fixed and Floating Charges as Security Mechanisms in Corporate finance Law in the United Kingdom." Юридична Украӥна. pp48-57.

16 [1903] 2 Ch 284.

17 See also Re Bond Worth Ltd [1980] Ch 228.

18 [2004] EWCA Civ 670. 
When the court determines whether a charge is floating or fixed, it ignores the narrative used by the parties, rather looks into the essence of the issue in question. In such a case, in Agnew v Commissioner of Inland Revenue ${ }^{19}$ Lord Millett stated that:

"In deciding whether a charge is a fixed or a floating charge, the Court is engaged in a twostage process. At the first stage, it must construe the instrument of charge and seek to gather the intentions of the parties from the language they have used. But the object at this stage of the process is not to discover whether the parties intended to create a fixed or a floating charge. It is to ascertain the nature of the rights and obligations which the parties intended to grant each other in respect of the charged assets. Once these have been ascertained, the Court can then embark on the second stage of the process, which is one of categorization. This is a matter of law. It does not depend on the intention of the parties. If their intention, properly gathered from the language of the instrument, is to grant the company rights in respect of the charged assets which are inconsistent with the nature of a fixed charge, then the charge cannot be a fixed charge however they may have chosen to describe it."

Lord Millett illustrated that Romer LJ's third distinguishing characteristic is the typical feature of a floating charge. In Arthur D Little Ltd $v$ Ableco Finance $L L C,{ }^{20}$ the plaintiff company (Arthur D Little Ltd) created a first fixed charge over its shareholding in a subsidiary company (CCL) and provided the guarantee of its liability for its two parent companies to Ableco. The chargor corporation reserved both voting and dividend rights concerning the shares. Even though the plaintiff's administrator was arguing that the charge created was a floating charge but the court followed Lord Millett's interpretation in Agnew case and held that the specific charge in question was fixed due to the following reasons: a) the charge was not float-

19 [2001] 2 AC 710.

20 [2002] 2 BCLC 799. ing over a body of fluctuating property; b) despite the plaintiff's voting and dividend rights, it failed to deal with the property in the usual course of business as well as it could not set out of, or else deal with the shares.

Therefore, the chargee was given control of the property. In National Westminster Bank plc v Spectrum Plus Ltd ${ }^{21}$ Lord Phillips MR took the opportunity to review the nature of a floating charge, observing that:

"The object of the floating charge was to provide security to the chargee in a form that would not inhibit the chargor from continuing to carry on its business. A floating charge was not, and is not, easy to define. Initially the courts tended to analyze it as a charge coupled with a license by the chargee to the chargor to dispose of the assets charged. Thus in Robson $v$ Smith [1895] Ch D 118 at p.124, Romer J approved the statement that floating charges "constitute a charge but give a license to the company to carry on its business'."

However, in Evans $v$ Rival Granite Quarries Ltd, ${ }^{22}$ Buckley LJ provided the following, more accurate, description of a floating charge:

"A floating security is not a future security; it is a present security, which presently affects all the assets of the company expressed to be included in it. On the other hand, it is not a specific security; the holder cannot affirm that the assets are specifically mortgaged to him. The assets are mortgaged in such a way that the mortgagor can deal with them without the concurrence of the mortgagee. A floating security is not a specific mortgage of the assets, plus a licence to the mortgagor to dispose of them in the course of his business, but is a floating mortgage applying to every item comprised in the security, but not specifically affecting any item until some event occurs or some act on the part of the mortgagee is done which causes it to crystallize into a fixed security."

\section{Book Debts}

Book debts are "debts arising in a business in which it is the proper and usual course to

21 [2004] EWCA Civ 670.

22 1910] 2 KB 979. 
keep books, and which ought to be entered in such books". ${ }^{23}$ During business, usually, customers owe money (debts) to the company for the products or services provided by it. Very often, the company ${ }^{24}$ does not wait for repayment of debts by the customer. Instead, it borrows money from the creditors against unpaid debts. The court recurrently receives the controversial question of considering the changing nature of book debts whether a fixed charge could be created over such debts. ${ }^{25}$

In Siebe Gorman \& Co Ltd v Barclays Bank $L t d,{ }^{26}$ the plaintiff (company) approved a debenture in favor of the defendant (bank), where the security was articulated to be a 'first fixed charge' over the entire of its existing and forthcoming book debts. The debenture had the followings: a) it required the plaintiff to pay the earnings of the entire book debts into the defendant's bank account; b) it had forbidden the plaintiff that without receiving defendant's consent, it was barred from charging or assigning its book debts.

The Slade J held that the plaintiff's (company) charge over its receivables was fixed charge because the above-mentioned two restrictions prevented the plaintiff from exercising its power to deal with the book debts and gave control to the defendant, therefore, the charge was not a floating charge. In contrast, the charge was held to

23 Official Receiver $v$ Tailby (1886) 17 QBD 88.

24 Yahanan, A., Febrian, F., \& Rahim, R. A., 2017, "The Protection of Consumer Rights for Aviation Safety and Security in Indonesia and Malaysia," Sriwijaya Law Review, 1(1), 027-043.

25 Ji Sun, Li Ding, Jie Michael Guo, and Yichen Li. 2016. "Ownership, Capital Structure and Financing Decision: Evidence From the UK," The British Accounting Review 48 (4), pp448-463.

26 [1979] 2 Lloyd's Rep 142. be a floating charge in Chalk $v$ Kahn, ${ }^{27}$ because chargee had no control over the account, as he was required to deposit the earnings into a particular bank account, which was located in a different bank.

However, in Re New Bullas Trading $L t d{ }^{28}$ the Court of Appeal reached an exceptionally controversial decision, where it was held that it was possible to create a joint fixed and floating charge over book debts. In this case, a fixed charge was created over uncollected book debts but as soon as the earnings of the debts were credited into a particular bank account, a floating charge was taking effect over them. The judgment of Re New Bullas had received a lot of criticism. Lord Millett stated in Agnew $v$ Commissioner of Inland Revenue $^{29}$ that the decision of New Bullas 'to be fundamentally mistaken'. The debenture drafted in Agnew followed New Bullas but the Privy Council held that "where the chargor company is free to deal with the charged asset(s) in the ordinary course of business it must be construed as a floating charge. However, where the chargee retains control over the debts and their proceeds to severely restrict the company's freedom to deal with them, as in Siebe Gorman, it will be a fixed charge". Therefore, the Privy Council abandoned the concept of a combined charge.

The defendant Spectrum (chargor) in National Westminster Bank plc v Spectrum Plus $L t d{ }^{30}$ approved a fixed (definite) charge to the plaintiff (N.W. bank) over its book debts. Clause 5 of the debenture stated:

"With reference to the book debts hereby specifically charged [Spectrum] shall pay into

[2000] 2 BCLC 361.

28 [1994] 1 BCLC 485.

[2001] 2 AC 710.

30 [2004] EWCA Civ 670. 
[Spectrum's] account with [National Westminster Bank] all moneys which it may receive in respect of such debts and shall not without the consent of [the bank] sell, factor, discount or otherwise charge or assign the same in favour of any other person or purport to do so and [Spectrum] shall if called upon to do so by [the bank] from time to time execute legal assignments of such book debts and other debts to [the bank]."

The earnings from the book debts were paid into the Spectrum's account but it was constantly overdrawn and Spectrum was allowed to draw money as and when required. After Spectrum went into insolvency, the plaintiff (bank) wanted a declaration from the court about the debenture, which created a fixed charge over the defendant's book debts and its earnings. Nevertheless, the Crown argued that the debenture simply created a floating charge. Thus tax claims which were outstanding by the defendant should take priority over the plaintiff (bank). The trial judge did not follow Re New Bullas and Siebe Gorman (above), instead applied the decision of Agnew (above) and held that the charge was floating because the defendant (company) was permitted to use the earnings of the debs in the regular course of business. The plaintiff (bank) successfully appealed to the Court of Appeal, where Lord Phillips MR had delivered the principal verdict. His Lordship explained that although the Privy Council in Agnew scrutinized the judgment was wrong in Re Bullas, but it was not open to the Court of Appeal to pronounce its opinion in such a way. He further stated:

"So far as the doctrine of precedent is concerned, therefore, there is no English decision which permits this court to disregard the decision of the Court of Appeal in Re New Bullas that it is possible to have a fixed charge over book debts notwithstanding that the chargor is entitled to collect and use the proceeds of the debts, which are agreed to be subject only to a floating charge."

Further, it was held that the decision in Siebe Gorman was rightly determined because the debenture was limited the company's capability to draw from the bank account, where the earnings of its book debts were received. It will be recalled that Slade J had held that the charge on book debts was fixed. The Court of Appeal illustrated that in Siebe Gorman, the kind of debenture used was being followed for approximately twenty-five years. Therefore, it held that the type of debenture had, traditionally, acquired meaning. Lord Phillips thus concluded as follows:

"Slade J could properly have held the charge on book debts created by the debenture to be a fixed charge simply because of the requirements (i) that the book debts should not be disposed of prior to collection and (ii) that, on the collection, the proceeds should be paid to the Bank itself. It follows that he was certainly entitled to hold that the debenture, imposing as he found restrictions on the use of the proceeds of book debts, created a fixed charge over book debts."

As expected, a seven-member House of Lords reversed the verdict of the Court of Appeal and overruled Siebe Gorman and Bullas. The House had followed the line of analysis taken by the Privy Council in $\mathrm{Ag}$ new and held that "even though it is possible to create a fixed charge over book debts and their proceeds (Tailby v Official Receiver), the charge in the present case was a floating charge". Lord Scott delivered the principal judgment and stated that the capability of the chargor to carry on to deal with the charged property makes it as a floating charge. The earnings should be paid into a 'blocked' account to create a fixed charge over book debts, Lord Scott reasoned:

"The bank's debenture placed no restrictions on the use that Spectrum could make of the 
balance on the account available to be drawn by Spectrum. Slade $\mathrm{J}$ in [Siebe Gorman] thought that it might make a difference whether the account was in a credit or debit. I must respectfully disagree. The critical question, in my opinion, is whether the charger can draw on the account. If the chargor's bank account were in debit and the charger had no right to draw on it, the account would have become, and would remain until the drawing rights were restored, a blocked account so long as the charger can draw on the account, and whether the account is in credit or debit, the money paid in is not being appropriated to the repayment of the debt owing to the debenture holder but is being made available for drawings on the account by the charger."

\section{Priority}

The common regulation is that security interests get priority in terms of their formation. In spite of this, as seen earlier, a characteristic of the floating charge is that the corporation is able to carry on to deal with the charged properties in the regular course of trade. For that reason, a fixed charge can be formed which will get priority over a former floating charge. In order to defend the floating charge priority, it is possible for the chargees to include a so-called 'negative pledge clause' in the charge. This would prohibit the chargor from creating an equal charge, which positions with (pari passu) or in priority to the former floating charge. Such a limitation is not incompatible with the character of a floating charge. ${ }^{31}$

In Re Brightlife Ltd, a charge over book debts was given by Brightlife Ltd to its bank Norandex and it was a "first specific charge." The charge contained that without written consent from the bank, Brightlife could not sell, issue or reduce debts. A week before a voluntary winding up resolution was passed, a debenture holder sent a notice to the Brightlife converting the floating charge into a fixed charge. Based on the

31 Re Brightlife Ltd [1987] Ch 200. public policy ground, the counsel argued that it required crystallizing events should be limited because without knowledge of debenture holder or corporation an automatic crystallization clause could take into effect. As a result, it could be detrimental to a third party since it lacks registration. In this case, the counsel referred to $R v$ Consolidated Churchill Copper Corp $L t d,{ }^{32}$ in which Berger $\mathrm{J}$. discarded the notion of a "self-generating crystallization". Hoffman J. held that in certainty, the charge on book debts was a floating charge, which was crystallized a week before, therefore, shall get priority over all other debts. Following Re Manurewa Transport $L t d,{ }^{33}$ crystallisation clauses were an essential thing of parties' freedom to contract and the Parliament should deal with the policy objections. His Lordship noted numerous statutes, which included priority over preferential debts and opined that if a corporation is allowed to carry on to make use of book debts without the permission of the chargee, then it would be a floating charge. He added further that even though clause 3(A)(ii)(a) was referring to a 'first specific charge' over book debts and others, "the rights over the debts created by the debenture were in my judgment such as to be categorized in law as a floating charge." 34

Nevertheless, it is to be noted that the subsequent chargee will not lose priority except he is genuinely aware of the 'negative pledge clause.' However, only a simple notice of the previous floating charge will not be enough. ${ }^{35}$ In Wilson $v$ Kelland case, a

\footnotetext{
[1978] 5 WWR 652, Canadian Case.

[1971] NZLR 909.

34 Mark J Flannery, and Robert R. Bliss. 2019. "Market Discipline in Regulation: Pre-and PostCrisis," Oxford Handbook of Banking 3.

35 Wilson v Kelland [1910] 2 Ch 306.
} 
floating charge was created by the company over its undertaking and conditions of the charge limited the right ${ }^{36}$ to create any more charges. Eve J. held that even though the charge was registered, which gives notice to the world that the charge existed but did not imply any special limitations to the company that it could not deal with its assets. This decision was followed by the Supreme Court of Malaysia in United Malayan Banking Corporation Bhd v Aluminex (M) Sdn Bhd \& Anor. $^{37}$

Where there are competing floating charges, the leading opinion is that the first in time will get priority over others. Nevertheless, if any party agrees that the corporation may create a successive floating charge and then it will take priority or rank pari passu with the previous floating charge. ${ }^{38}$ In Re Benjamin Cope \& Sons Ltd, it stated that the first in creation prevails. If two floating charges exist on the same asset, then the floating charge that was created earlier will get priority over the later floating charge. This decision indicates that the first in creation prevails provided that both floating charges are registered.

\section{Registration}

It is reasonable that before lending any money to any company, a creditor would like to find out the level of its indebtedness. Therefore, as per section 860 of the CA 2006 , it is obligatory for a company to register certain categories of charge in details on its property. These include, among others: a) a charge for the reason of securing any issue

\footnotetext{
36 Nurhidayatuloh, N., \& Febrian, F, 2019, “ASEAN and European Human Rights Mechanisms, What Should be Improved?," Padjadjaran Journal of Law, 6(1), pp151-167.

37 [1993] 3 MLJ 587 (SC).

38 Re Benjamin Cope \& Sons Ltd [1914] 1 Ch 800.
}

of debentures; b) a charge on or on any interest in land, but not including a charge for any rent or other periodical sum issuing out of the land; c) a charge on book debts of the corporation; d) a floating charge on the company's undertaking or assets.

\section{The Twenty-first Day Registration Obli- gation}

The primary responsibilities for a company for registration are contained in ss.860 and 870 of part 25 of the CA 2006, which provide that "prescribed particulars of certain categories of charges created by a company, together with the instrument creating it, must be delivered to or received by the Companies Registrar within 21 days of the creation of the charge. Failure to deliver the particulars to the Registrar within the twenty-one-day period renders the charge void against a liquidator or any creditor of the company". ${ }^{39}$ In Smith v Bridgend, as per the standard building contract, a contractor was authorized to seize plant and equipment from a place and could put up for sale to recover due payments under the contract, ahead the other contractor becoming bankrupt. When the company entered into receivership, the contractor vacated the place. However, the defendant found a different contractor who was willing to carry on the work using similar substantial equipment. The contractor's receiver argued that even though the power amounted to a charge over the company's properties but it should have been registered at Companies House. The court held that the clause operated as a floating charge and due to non-registration, the charge was void as against the administrator or liquidator. Therefore, a charge should be registered under the CA 2006. 39 S.874, CA 2006; see also Smith v Bridgend Coun-
ty Borough Council [2002] 1 BCLC 77. 
It should be noted that if any creditor fails to register the charge, it will not void the loan, rather, the lender will be treated as an unsecured creditor. If any company or its officer fails to register the charges, then all of them shall be held liable to a fine. ${ }^{40}$ When a charge is registered, it is valid from the date of its creation, which is termed as the 21-day invisibility problem. ${ }^{41}$ When anyone checks the Register, he or she must not assume that the list is all-inclusive since there may be a charge for which the 21-day period is still running. Moreover, a company is required to preserve a complete list of all fixed and floating charges at its registered headquarters under section 876. Even though, if a company fails to maintain such a register does not affect the validity of the charge, but if any officer knowingly authorizes or permits the omission of a required entry shall be liable to a fine.

While a charge is registered under CA 2006, the Registrar ought to issue an official document stating the sum secured by the charge. The documentation is convincing evidence that the company has complied with the statutory registration requirements under the CA 2006. Once registered, the charge cannot be set aside if any particulars are incorrect. ${ }^{42}$ Registration is a completion requirement and does not establish priority, which, as we saw above, depends on the date of the charge that was created. The court held that if any creditor who must reasonably search the register, will be consid-

40 Note 37, s.860(4).

41 See the CLRSG's Consultation Document Registration of Company Charges (October 2000), para. 3.79 .

42 Re Eric Holmes (Property) Ltd [1965] Ch 1052; Re CL Nye Ltd [1971] Ch 442. ered to have constructive notice about the charge. ${ }^{43}$

\section{Rectifying the Register ${ }^{44}$}

If the Register needs to be rectified, it may be possible "where the court is satisfied that failure to register within the required period, or that an omission or misstatement of any particular was accidental or inadvertent, or is not of a nature to prejudice creditors or shareholders of the company, or that on other grounds it is just and equitable to grant relief'. ${ }^{45}$ Usually, the court grants leave to register out of time if the corporation is solvent and subject to the privileges of the prevailing secured creditors. ${ }^{46}$

\section{Prevention of Floating Charges}

Section 245 of the Insolvency Act 1986 invalidates "a floating charge created within 12 months (termed 'the relevant time') prior to the onset of insolvency unless it was created in consideration for money paid or goods or services supplied at the same time as or subsequent to the creation of the charge. The 'relevant time' is extended to two years where the charge is created in favor of a 'connected person'". However, s.245(4) provides that "a floating charge created in favor of a non-connected person within the 'relevant time' (i.e., twelve months) will not be invalidated if the company was able to pay its debts at the time the charge was created and did not become unable to do so as result of creating the charge". However, it is to be noted that this provison does not continue to charges created in support of connected persons. Section 249 defines the phrase 'connected person' as mean-

\footnotetext{
43 Siebe Gorman \& Co Ltd v Barclays Bank Ltd [1979] 2 Lloyd's Rep 142.

44 See s.873, CA 2006.

45 Note 42, s.404.

46 See Re IC Johnson \& Co Ltd [1902] 2 Ch 101.
} 
ing: "a director or shadow director of the company; or "an associate of a director or shadow director of the company"; or "an associate of the company."

The aim of s.245 is to preclude an unsecured creditor so that he cannot acquire a floating charge to secure his existing loan at the cost of other unsecured creditors. In $R e$ Yeovil Glove Co Ltd ${ }^{47}$ the company's overdraft stood at around $£ 67,000$ and the bank sought security. The company, therefore, created a floating charge over its assets. On this basis, the bank continued to meet cheques drawn by the company amounting to around $£ 110,000$. Within twelve months of creating the charge the company went into insolvent liquidation. In addition to its overdraft with its bankers, the company also owed $£ 94,000$ to unsecured creditors. The unsecured creditors argued that the floating charge was invalidated by virtue of $\mathrm{s} .322$ CA $1948 .{ }^{48}$ They contended that no 'money' had been paid to the company by the bank, as would be required to prevent the charge from being invalidated. However, it was held that the liquidation overdraft was not the same debt as had existed when the charge was first created as the bank had permitted the company to continue drawing cheques on its account between the time of the charge and the liquidation, during which time around $£ 111,000$ had been paid in and drawn out. The sums paid into the account following the creation of the charge paid off the original debt to the bank. The company's cheques that had been met following the charge thus created a new debt (i.e., money paid subsequently to the granting of the charge). In short, the bank had provided new

[1965] Ch 148.

48 Now s. 245 of the IA 1986. 'money' to the company, which stood as its overdraft at the time of the liquidation. The charge was, therefore, valid.

\section{CONCLUSION}

Significantly, under CLRSG proposals, registration would no longer be 'a mere perfection requirement but would become a priority point.' Under this proposal, which is based upon Article 9 of the United States Uniform Commercial Code, all that was filed would be a notice ('financing statement') giving details of the assets over which the filer had taken or intended to take security and more specific details, as well as the name and address of the creditor from whom anyone searching the record could acquire more information. The 21-day registration rule would be abandoned, as well as an obligation that the charge instrument is presented with the submission for registration. Detailed rules are set out that would form the foundation for a system below which the priority of registered charges would be determined by their dates of registration at Companies House. The time between creation and registration would not be significant because there would not be any time of invisibility. So, registration would not be a perfection requirement anymore and would just turn into a priority point. ${ }^{49}$

Moreover, the problem of fulfillment with the registration requirements must fall over those who present the documentation because they were better positioned to ascertain whether what they convey satisfies the legislative requirements. Therefore, any legal responsibility for factual error in the record should be placed with them. According-

49 Adrian J Walters, 2015. "Statutory Erosion of Secured Creditors' Rights: some Insights From the United Kingdom," U. Ill. L. Rev. 543. 
ly, the Registrar's certificate should be decisive only as far as it is feasible for it to be so. ${ }^{50}$ To achieve this several objective options could be explored. The most radical of these is to dispense with the requirement that the document creating the charge should be delivered to the Registrar. In its place, the requirement could be that the company only submits details of the charge, which would contain the time of its creation. The Companies House would merely validate that the requisite details had been filed on time. The presenters would be completely accountable for the details that appear on the public record. $^{51}$

Furthermore, the range of the categories of charges to be registered should be widened because the concept of 'book debts' could be broadened by dropping the reference to 'book' but retaining the concept of 'debt,' thereby encompassing a wider category of money obligation. Every charge on indemnity policies should be made registrable, irrespective of whether or not other contingent debts are registrable. Finally, in order to enhance the value of floating charges, the parties should be permitted to register negative pledge clauses if they so wish. This would provide for constructive notice of the assurance either from the time the charge was created or from the time of its registration.

\section{REFERENCES}

Aiyar, Shekhar, Charles W. Calomiris, John Hooley, Yevgeniya Korniyenko, and Tomasz Wieladek. 2014. "The International Transmission of Bank Capital Require-

50 Armour, John and Daniel Awrey, 2016, Principles of Financial Regulation. Oxford: University Press, p26.

51 Quaglia, Lucia, 2019, "European Union Financial Regulation, Banking Union, Capital Markets Union and the UK," Palgrave Macmillan, pp67-69. ments: Evidence from the UK." Journal of Financial Economics, 113 (3).

Armour, John and Daniel Awrey. 2016. Principles of Financial Regulation. Oxford: University Press.

Ferran, E. 2014. Company Law and Corporate Finance. Oxford: Oxford University Press.

Flannery, Mark J. and Robert R. Bliss. 2019. "Market Discipline in Regulation: Pre-and Post-Crisis." Oxford Handbook of Banking 3.

Nurhidayatuloh, N., \& Febrian, F. 2019. ASEAN and European Human Rights Mechanisms. What Should be Improved?. Padjadjaran Journal of Law. 6(1).

Quaglia, Lucia. 2019. "European Union Financial Regulation, Banking Union, Capital Markets Union and the UK." Palgrave Macmillan.

Walters, Adrian J. 2015. "Statutory Erosion of Secured Creditors' Rights: Some Insights From the United Kingdom." U. Ill. L. Rev. Volume 543.

Yahanan, A., Febrian, F., \& Rahim, R. A. 2017. "The Protection of Consumer Rights for Aviation Safety and Security in Indonesia and Malaysia." Sriwijaya Law Review. 1(1).

Zhuravel, Mariana. 2015. "Fixed and Floating Charges as Security Mechanisms in Corporate Finance Law in the United Kingdom." Юридична Украӥна.

Sun, Ji, Li Ding, Jie Michael Guo, and Yichen Li. 2016. "Ownership, Capital Structure and Financing Decision: Evidence from the UK." The British Accounting Review, 48 (4).

Talbot, Lorraine. 2015. Critical Company Law. Routledge. 